\title{
メニスカス形状からの液体酸化物の表面張力と

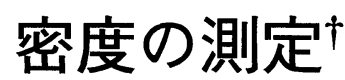

\author{
余仲達地向井楠宏
}

九州工業大学工学部物質工学科

J. Japan Inst. Metals, Vol. 59, No. 8 (1995), pp. 806-813

\section{Measurement of Surface Tension and Density of Liquid Oxides from Meniscus Shape}

\author{
Zhongda $\mathrm{Yu}$ and Kusuhiro Mukai \\ Department of Materials Science and Engineering, Faculty of Engineering, \\ Kyushu Institute of Technology, Kitakyushu
}

\begin{abstract}
A method to measure surface tension of a liquid was developed from the analyses of the observed static shape of meniscus formed along a vertical cylindrical rod which was dipped in the liquid in a cylindrical crucible. This method enables us to measure surface tension of the liquid in static state for the case where contact angle between the liquid and the rod is smaller than $90^{\circ}$.

Simultaneously, the density of the liquid can be also measured from the observed shape of a cylindrical crucible and that of the liquid above the crucible.

An apparatus for measuring the surface tension and density with this method was constructed, and it was confirmed to have a high precision and reliability for the measurements in the range from room temperature to $1673 \mathrm{~K}$ by using water and liquid $\mathrm{B}_{2} \mathrm{O}_{3}$.

By using the apparatus, the surface tension and density of $\mathrm{Fe}_{t} \mathrm{O}-\mathrm{SiO}_{2}-\mathrm{Al}_{2} \mathrm{O}_{3}$ slags were precisely determined at $1673 \mathrm{~K}$ under an argon atmosphere in a strictly sealed chamber.

Thus, this method and apparatus can be widely used to measure precisely the surface tension and density of liquid oxides in the static state and controlled atmospheres.
\end{abstract}

(Received December 26, 1994)

Keywords: surface tension, density, liquid, meniscus shape, controlled atmosphere, liquid oxides, $\mathrm{Fe}_{t} \mathrm{O}-\mathrm{SiO}_{2}-\mathrm{Al}_{2} \mathrm{O}_{3}$ slags

\section{I . 緒言}

酸化鉄含有スラグは，金属製精錬に広く用いられており，こ のスラグの表面張力や密度の測定は, 製精鍊プロセスの改良, 開発の基礎として重要である。最近, 著者らは, $\mathrm{SiO}_{2}(\mathrm{~s})$ $\left(\mathrm{Fe}_{t} \mathrm{O}-\mathrm{SiO}_{2}\right),\left(\mathrm{Fe}_{t} \mathrm{O}-\mathrm{SiO}_{2}-\mathrm{Al}_{2} \mathrm{O}_{3}\right)$ スラグ系の局部溶損現象を観 察し，局部溶損部において，マランゴニ効果に起因すると考兄 られるスラグメニスカスの特徵的な運動が局部溶損に密接に関 わっていることを明らかにした(1). それ故, この運動を解明す るには, 酸素分圧 $P_{\mathrm{O}_{2}}$ を局部溶損観察時と同じ值に制御した状 態で, スラグの表面張力と密度の值を精度良く測定する必要が ある. しかしながら, スラグの表面張力, 密度に及ぼす $\mathrm{Fe}_{t} \mathrm{O}$ 組成の影響は䨌囲気中の $P_{\mathrm{O}_{2}}$ に敏感であるにもかかわらず，酸 素分圧を十分に制御した状態でのこの系の表面張力に関する報 告は数少ない.

高温での溶融酸化物の表面張力の測定によく用いられる方 法は, 最大泡圧法 ${ }^{(2)}$, 浸漬円筒法 ${ }^{(3)}$, 懸滴法 ${ }^{(4)}$, 静滴法 ${ }^{(5)}$,

† 1993年10月日本金属学会秋期大会に招いて発表

† 九州工業大学大学院生, 現在 : 黒崎割業(侏)
Padday's Cone Method(6)である.

静滴法は力学的に静的な状態で表面張力を測定できる. しか


といら解析結果 ${ }^{(7)}$ が報告されている. スラグの場合, 支持台と してよく用いられる反応性の小さい白金合金とスラグとの接触 角は $90^{\circ}$ 以下であるので, 静滴法では大きな測定䛊差が生じる. Padday's Cone Method ${ }^{(6)}$ も静的な測定法であり, 液体に部分 的に浸漬されたコーン(Cone)に動く最大過㮃力 (Maximum excess force)の測定から液体の表面張力を求める.しかし，この 方法では, 表面張力の算出に際して, 別にスラグの密度の值が 必要であり, しかも長い実験時間 $(17 \sim 69 \mathrm{~h})$ 括よび複雑な実験 操作を必要とするなどの欠点があるのであまり使用されていな い.

その他の方法はすべて基本的に動的な状態のもとでの表面張 力の測定法である.これらの測定法の中で比較的に広く用いら れている最大泡圧法と浸漬円筒法による測定值の間には，それ ぞれの測定精度に基づく見積誤差より数十倍以上も大きな差が 生じる場合のあることが報告されている ${ }^{(8)}$ ，浸漬円筒法は装置 が大がかりで, $P_{\mathrm{O}_{2}}$ の調整も難しい. 著者らは最大泡圧法を用 いて本系のスラグの表面張力の測定を試みたが, 融点付近で 
は，白金毛細管内に高融点のスピネルが生成し，毛細管が閉塞 して測定が不可能となることが分かった。

溶融スラグの密度は主として最大泡代法, アルキメデス法, 静滴法によって測定されている.酸化鉄を含むスラグの密度 は, 表面張力と同様, 雾囲気中の酸素分圧 $P_{\mathrm{O}_{2}}$ に依存する。 ᄂ たがって,このように $P_{\mathrm{O}_{2}}$ にって密度が変化するスラグの表 面張力の測定には，同一雾囲気のもとでの密度の值が必要であ る、アルキメデス法は，一般に $P_{\mathrm{O}_{2}}$ の制御が難しく，得られた 測定值は測定者の注意深さ化左されやすい，最大泡右法て は, 測定法自身の誤差に加㫕て, 温度, 気泡生成用ガスの酸素 分圧の調整が不十分な場合には, 密度は高くなる傾向がある(9).

このよ5K，酸化鉄含有スラグの表面張力と密度関する従 来の測定法炕は一長一短があり，より信頼性が高い湘定值を得 るルは，従来の測定法とは異なり，上記問題点を解消し得るよ らな新しい測定法の開発が望まれる。皇こで, 本研究では, 固 体白金円筒の周りに形成される溶融スラグのメニスカス形状か ら，雾团気を制御しらる状態のもとで表面張力を測定するため の解析法を開発し，装置を製作した. 本測定法は静的測定法て ある静滴法と測定原理は基本的に同様のるのである。 そして， 本測定法を用いて $\mathrm{Fe}_{t} \mathrm{O}-\mathrm{SiO}_{2}$ 乱よび $\mathrm{Fe}_{t} \mathrm{O}-\mathrm{SiO}_{2}-\mathrm{Al}_{2} \mathrm{O}_{3}$ 系スラグ の表面張力の測定を行った。同時に，スラグを白金るつぽにス ラグ表面がるつぼ上端より盛り上がるまで入れ，その夜面の形 状を解析することにより, 密度を測定する方法を開発し, 上記 表面張力測定と同一装置を用いて, 表面張力の測定と同時に密 度の測定を行った。

\section{II. 表面張力の測定}

\section{1. 原 理}

表面張力の湘定は，Fig. 1 K示すよう火，水平に設置した 白金るつぼ(密度測定の場合と同一寸法)に液体を満たし，その 真中K白金円筒 (外径 $6 \times 10^{-3} \mathrm{~m}$ ) を垂㨁に浸漬する．白金円 筒の周囲に形成される液体のメニスカスの形状を測定し, Laplace 式を用いて解析することによって表面張力を湘定す る、るつぼと白金円筒との間代形成される液体のメニスカス形 状は，Fig. 1 に示すように，z軸に対称な回転体と考支てよ

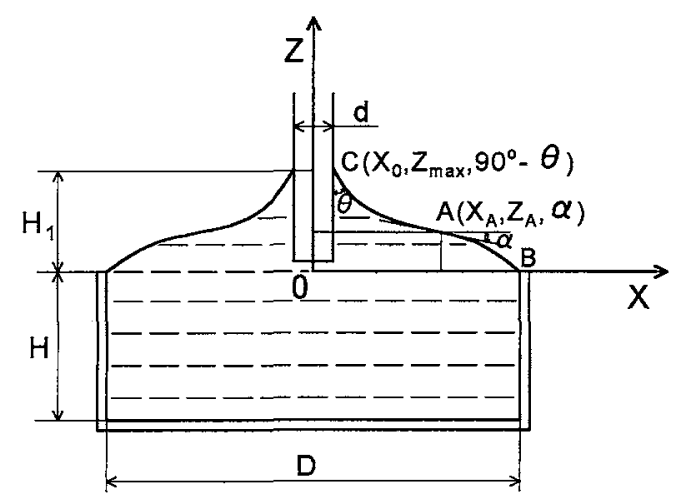

Fig. 1 Meniscus shape above crucible.
い.メニスカスの液面線は次の Laplace 式 $(1) \sim(3)$ で表さ れる。

$$
\begin{aligned}
& y\left(1 / R_{1}+1 / R_{2}\right)=\rho g z+C_{0} \\
& 1 / R_{1}=\left(\partial^{2} z / \partial x^{2}\right) /\left(1+(\partial z / \partial x)^{2}\right)^{3 / 2} \\
& 1 / R_{2}=(\partial z / \partial x) / x /\left(1+(\partial z / \partial x)^{2}\right)^{1 / 2}
\end{aligned}
$$

ここで, $\gamma$ は表面張力 $(\mathrm{N} / \mathrm{m}), R_{1}, R_{2}$ は表面上の任意の点に打 ける主曲率半径 $(\mathrm{m}), z$ はるつぼの上端からの夜面の高さ $(\mathrm{m})$, $g$ は重力加速度 $\left(\mathrm{m} / \mathrm{s}^{2}\right), C_{0}$ は定数である.

Fig. 1 K示すよう火, 变曲点 $\mathrm{A}$ では,

$$
z=Z_{\mathrm{A}}: x=X_{\mathrm{A}}, R_{1}=\infty, R_{2}=-\sin \alpha / X_{\mathrm{A}}
$$

が成立する。これを式(1) 亿代入すると，

$$
C_{0}=-\left(\gamma \sin \alpha / X_{\mathrm{A}}+\rho g Z_{\mathrm{A}}\right)
$$

式(5)を式(1)飞代入すると次の式 (6)を得る.

$$
1 / R_{1}+1 / R_{2}=(\rho g / \gamma)\left(z-Z_{\mathrm{A}}\right)-\sin \alpha / X_{\mathrm{A}}
$$

式(4)の境界条件を用い礼ば，式(6)は数值的に解ける。こ のよ5にして計算されるメニスカスの液面線は，式(6)から

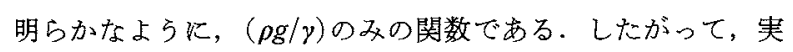

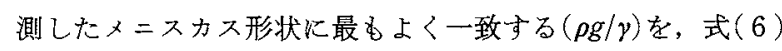
からコンピューターを用いて求めることができる.この結果と 而節で求めた密度 $\rho$ を用い京ば, 表面張力 $\gamma$ が求められる.

\section{2. 誤差の検討}

(1) メニスカス形状における変曲点

Fig. 1 に示寸よ5に，右側のメ二スカス形状でAからC での曲線は上に凸であるが，AからBまでの曲線は下に凸で ある.すなわち, 本測定系ではこのメニスカス形状変曲点

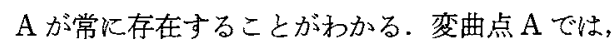

$$
\left(\partial^{2} z / \partial x^{2}\right) \mid\left(X_{\mathrm{A}}, Z_{\mathrm{A}}\right)=0
$$

が成立する，それ故，実測したメニスカス形状を 2 次微分す れば，その変曲点 $\mathrm{A}$ の來標 $\left(X_{\mathrm{A}}, Z_{\mathrm{A}}\right)$ と傾き角 $\left(180^{\circ}-\alpha\right)$ が求め られる。

\section{（2）メニスカス形状算出用のきざみ幅}

浸漬円筒の外径を $6 \times 10^{-3} \mathrm{~m}$, 変曲点 $\mathrm{A}$ の座標を $\left(8 \times 10^{-3}\right.$ $\left.\mathrm{m}, 1.264 \times 10^{-3} \mathrm{~m}\right)$, 変曲点 $\mathrm{A}$ での接楾の傾きを $(180-12)^{\circ}$, $(\gamma / \rho)$ を $10^{-4} \mathrm{~m}^{3} \mathrm{~s}^{-2}$ とした場合を取り上げる.なお，水，ス ラグを含む大部分の液体の $(\gamma / \rho)$ は $0.8 \sim 1.2 \times 10^{-4} \mathrm{~m}^{3} \cdot \mathrm{s}^{-2}$ の 間にある。さざみ幅が $1 \times 10^{-4} \mathrm{~m}, 5 \times 10^{-5} \mathrm{~m}, 1 \times 10^{-5} \mathrm{~m}$ の場 合に, 式(6)より算出されるメニスカスの夜面形状を Fig. 2



Fig. 2 Meniscus shape obtained by numerical calculation. 


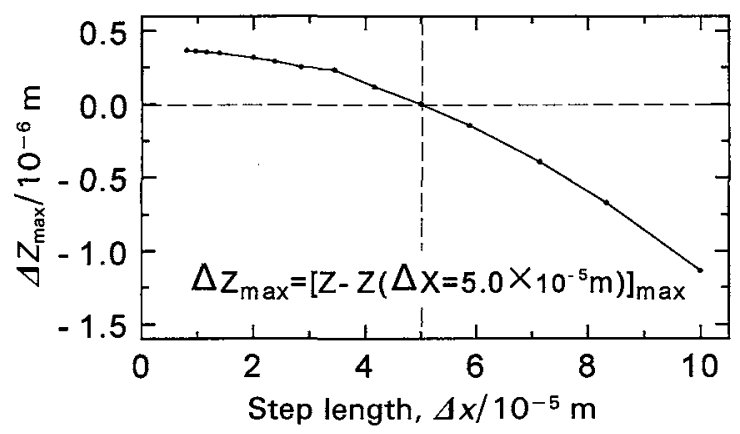

Fig. 3 Calculation error of meniscus shape.

に示す. Fig. 2 上り，三種類のきざみ幅で算出された液面形状 の差はほとんど識別できない，次に，きざみ幅が $5 \times 10^{-5} \mathrm{~m}$ の場合代算出されるメニスカスの液面形状を基準にして，各種 きざみ幅で算出したメニスカスの液面形状と基準液面形状との 間の最大高さの差 $\Delta Z_{\max }$ と, 接触角の差 $\Delta \theta$ を計算した。 その 結果を Fig. 3 K示す．図に示すように， $\Delta Z_{\max }$ はきざみ幅の 減少とと本火增加するが，その増加の割合は，小さくなり，き ざみ幅が $1 \times 10^{-5} \mathrm{~m}$ より小さくなると， $\Delta Z_{\max }$ の值がほとん

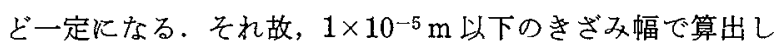
たメニスカスの形状は, 実際のメ二スカス形状に一致する。

Fig. 3 亿拈いて，きざみ幅を零に外挿して得られる $\Delta Z_{\max }$ の 值ときざみ幅が $5 \times 10^{-5} \mathrm{~m}$ の場合の $\Delta Z_{\max }$ との差は，きざみ 幅が $5 \times 10^{-5} \mathrm{~m}$ の場合の入二スカス形状の最大計算誤差と見 なせる.Fig. 3 より，この最大計算誤差は $5 \times 10^{-7} \mathrm{~m}$ より さい. 同様に接触角の計算誤差 $\Delta \theta$ 6 $1.5^{\circ}$ 以内であることがわ かる. 本研究に用いた $5 \times 10^{-5} \mathrm{~m}$ のざみ幅でのメニスカス 形状の最大計算誤差 $5 \times 10^{-7} \mathrm{~m}$ は正節の 2-(2)で明らかにした メニスカス形状の実測精度 $\left(1 \times 10^{-5} \mathrm{~m}\right)$ より，1枌以上小さ い、それ故, きざ幅を $5 \times 10^{-5} \mathrm{~m}$ に取った場合の計算誤差 は, 測定誤差と比べれば無視し得る仼ど小さいことがわかる.

\section{(3) 形状測定}

浸漬円筒の外径を $6 \times 10^{-3} \mathrm{~m}$, 変曲点 $\mathrm{A}$ の座標を $X_{\mathrm{A}}=8 \times$ $10^{-3} \mathrm{~m}, Z_{\mathrm{A}}=1.264 \times 10^{-3} \mathrm{~m}$, 变曲点での接線の傾きを(180$12)^{\circ}$ ，きざみ幅を $5 \times 10^{-5} \mathrm{~m}$ として，( $(y / \rho)$ の值が $0.8 \times 10^{-4}$, $0.92 \times 10^{-4}, 1 \times 10^{-4}, 1.08 \times 10^{-4}, 1.2 \times 10^{-4} \mathrm{~m}^{3} \mathrm{~s}^{-2}$ の場合の メニスカスの液面形状を式 $(7)$ から算出した。 その結果を Fig. 4 亿示す. 図より，( $(y / \rho)$ の值がメ二スカスの液面形状に 大きな影響を与劣ることがわかる。（ $(\gamma / \rho)$ の值が $1 \times 10^{-4} \mathrm{~m}^{3}$ $\mathrm{s}^{-2}$ の場合に算出されたメニスカスの液面形状を基準にして, 各種 $(\gamma / \rho)$ の值で算出されたメニスカスの液面形状との $\Delta Z_{\max }, \Delta \theta$ を計算した。 その結果を Fig. 5 に示す。図より， $\Delta Z_{\max }$ は $(\gamma /$ $\rho)$ の増加とともに減少し, 父の勾配 $\Delta\left(\Delta Z_{\max }\right) / \Delta(\gamma / \rho)$ の絶対 值は $(\gamma / p)$ のきい汪ど小さくなる.すなわら，デジタイザー などによるメニスカスの形状の測定誤差 $\Delta\left(\Delta Z_{\max }\right)$ が一定の場 合, $\Delta\left(\Delta Z_{\max }\right)$ の変化に対応寸る $(\gamma / \rho)$ 変化量 $\Delta(\gamma / \rho)$ は, $(\gamma / \rho)$ 小さい汪ど減少する．このことは表面張力の算出精度 $\Delta(\gamma / \rho)$ が, 表面張力と密度の比 $(\gamma / \rho)$ が大きい汪ど悪くなるこ とを示している。デジタイザーの測定誤差 $\left(1 \times 10^{-5} \mathrm{~m}\right)$ が $\Delta\left(\Delta Z_{\max }\right)$ に等しいとした場合に，その誤差により生じる $(\gamma /$ $\rho)$ の变化量 $\Delta(\gamma / \rho)$ は, Fig. 5 より $\pm 0.5 \times 10^{-6} \mathrm{~m}^{3} \mathrm{~s}^{-2}$ 以下と

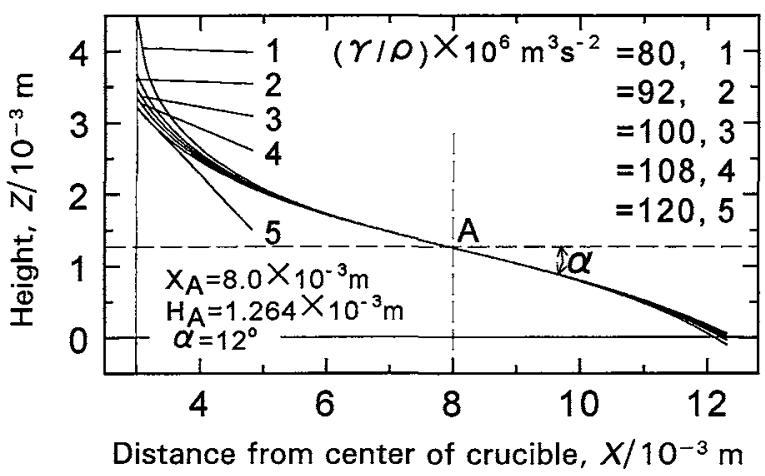

Fig. 4 Meniscus shape obtained by numerical calculation.
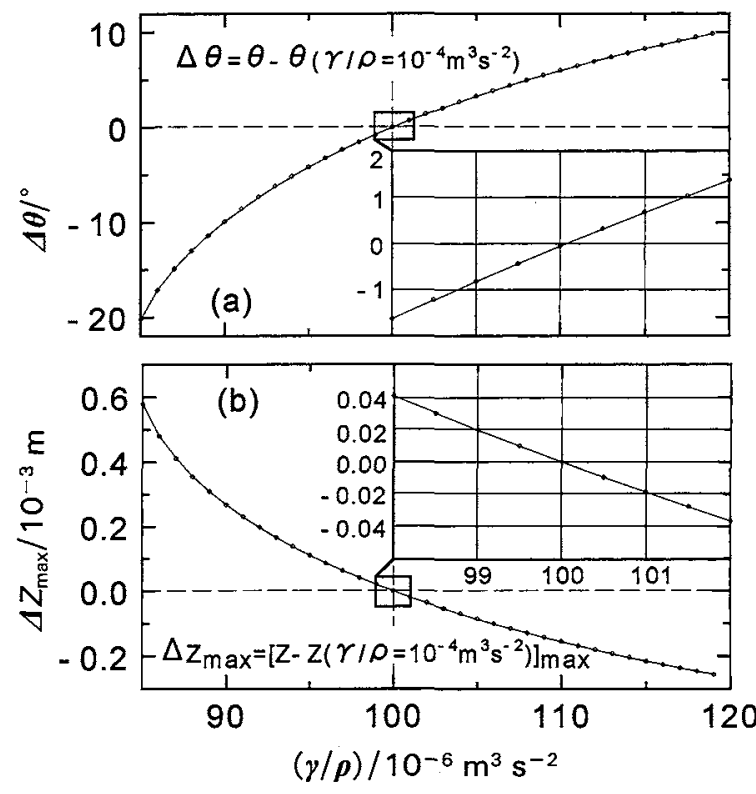

Fig. 5 Relation between $(\gamma / \rho)$ and $\Delta \theta(\mathrm{a})$, and $\Delta Z_{\max }$ (b) obtained by numerical calculation.

なる、なお，デジタイザーの入力誤差は $\pm 1.0 \times 10^{-4} \mathrm{~m}$ 以下で あり，写真撮影した後の実物に対する倍率は，本研究では10 倍以上であるので，デジタイザーによる形状測定誤差は $1.0 \times$ $10^{-5} \mathrm{~m}$ 以下と見なせる.この值を表面張力の相对誤差 $\left(\left|\gamma-\gamma_{0}\right|\right)$ $\left.\gamma_{0} \times 100 \%\right)$ にな特すと， $0.5 \%$ 以下となる。同様儿測定䛊差 $\left(1 \times 10^{-5} \mathrm{~m}\right)$ k対応する接触角の誤差 $\Delta(\Delta \theta)$ は $\pm 0.5^{\circ}$ 以下にな る.したがって，本測定法の計算の際住じる誤差は，表面張 力では0.5\%以下であり，接触角ではきざみ角に上る䛊差 $\left(1.5^{\circ}\right)$ と併せ $2^{\circ}$ 以下と見積もられる。

\section{（4）水の表面張力の測定}

実験に際して生じる䛊差を調べるために，室温でイオン交換 蒸留水の表面張力を測定した。実駼装置をFig. 6 亿示声。支 持台上に水平没置した白金るつぼに，洗浄瓶からイオン交換 蒸留水をFig. 6 炕示すよ5に水の表面がるつぼ上部より上に 盛り上がるまで静かに入れる。その後，円柱状ガラス(外径 $6 \times 10^{-3} \mathrm{~m}$ と $\left.8 \times 10^{-3} \mathrm{~m}\right)$ の一端を垂直にるつぼの真中に浸漬 




Fig. 6 Scheme of experimental apparatus for measuring the surface tension of water.

Table 1 Surface tension of water, $\gamma / \mathrm{mNm}^{-1}$.

\begin{tabular}{l|c|c|c}
\hline & Temperature, \\
Item & 291.5 & 296 & $297 \pm 1$ \\
\hline Present work & - & - & $72.3 \pm 0.7$ \\
\hline $\begin{array}{l}\text { Maximum bubble } \\
\text { pressure method }\end{array}$ & $72.20^{(10)}$ & $72.18^{(11)}$ & - \\
\hline Selected value $^{(12)}$ & 73.05 & 72.28 & 72.12 \\
\hline
\end{tabular}

する.メニスカスが静止後, A, B , C, D 四方向からるつぼおよ び水のメニスカスの形状を写真撮影する. メニスカスの液面を $z$ 軸対称と仮定する. 撮影したメニスカスの形状を測定し, 式 （1）～(4)，(6)を用いて解析することによりイオン交換蒸留 水の表面張力を求めた. このようにして求めた表面張力, 他の 研究者の測定值(10)(11), および化学便覧に採用されている 值 ${ }^{(12)}$ を Table 1 に示す. Table 1 に示すように，ガラス円柱 径と水の質量を種々変化させて得られた本測定法での水の表面 張力は $297 \pm 1 \mathrm{~K}$ で $71.59 \sim 72.97 \times 10^{-3} \mathrm{~N} \cdot \mathrm{m}^{-1}$ であり, その 平均値は $72.3 \pm 0.7 \times 10^{-3} \mathrm{~N} \cdot \mathrm{m}^{-1}$ となった。 この值を化学便 覧の推奖值 $72.12 \times 10^{-3} \mathrm{~N} \cdot \mathrm{m}^{-1}$ と比較すれば, 相対誤差は $1.2 \%$ 以内である.

\section{III. 密度の測 定}

\section{1. 測定原理}

密度の測定は, Fig. 7 に示すように, 水平に設置された白 金るつぼ(内径 $2.50 \times 10^{-2} \mathrm{~m}$, 深さ $1.20 \times 10^{-2} \mathrm{~m}$ ) にスラグ表 面がるつぼ上端より盛り上がるまでスラグを入れ，その液面の 形状を測定解析して，スラグの体積を求めることにより行われ る.この場合のるつぼと液面の形状は, Fig. 7 に示すように 軸に対称な回転体と考えられる. るつぼ上端上り上部の盛り上 がった液体の体積は, N-1 個の水平断面で輪切りにし, i-1 と i 間の輪切りにされた体積は放物面円錐台で近似する。すなわ ち，まず，Fig. 7 に示すように, $\mathrm{P}_{1}, \mathrm{P}_{2}, \mathrm{P}_{3}$ の三つの座標値よ り $x=A_{1} \mathrm{z}^{2}+B_{1} \mathrm{z}+C_{1}$ 曲線中の定数 $\mathrm{A}_{1}, \mathrm{~B}_{1}, \mathrm{C}_{1}$ を求め, $\mathrm{P}_{1}-\mathrm{P}_{2}$ の間の曲線を決める. 同様に, $\mathrm{P}_{2}, \mathrm{P}_{3}, \mathrm{P}_{4}$ の座標值から $\mathrm{P}_{2}-\mathrm{P}_{3}$

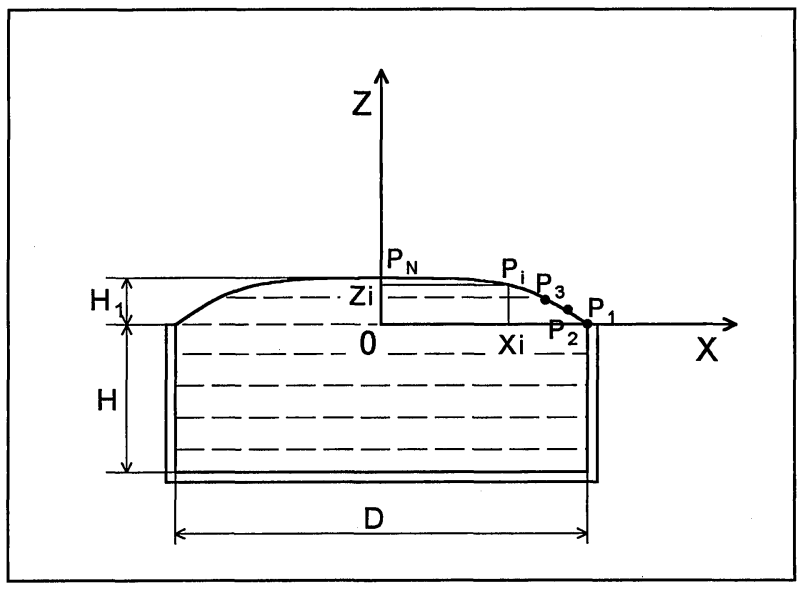

Fig. 7 Liquid shape above crucible.

の間の曲線を決めて行き順次この操作を繰り返して, 最後の 3 点 $\mathrm{P}_{\mathrm{N}-2}, \mathrm{P}_{\mathrm{N}-1}, \mathrm{P}_{\mathrm{N}}$ の座標值より, $\mathrm{P}_{\mathrm{N}-2}-\mathrm{P}_{\mathrm{N}}$ の間の曲線を決 める.このようにして， $\mathrm{P}_{1}$ から $\mathrm{P}_{\mathrm{N}}$ までの液面曲線を近似す る. その場合, 液体の全体積 V は次式 (8)で与えられる。

$$
V=\pi D^{2} H / 4+\pi \int_{\mathrm{P}_{1}}^{\mathrm{P}_{\mathrm{N}}}\left(A_{\mathrm{i}} z^{2}+B_{\mathrm{i}} z+C_{\mathrm{i}}\right)^{2} \mathrm{~d} z
$$

式( 8 )右辺の第二項に $\mathrm{P}_{1}-\mathrm{P}_{2}, \mathrm{P}_{2}-\mathrm{P}_{3}, \cdots, \mathrm{P}_{\mathrm{i}-1}-\mathrm{P}_{\mathrm{i}}, \cdots, \mathrm{P}_{\mathrm{N}-1}-\mathrm{P}_{\mathrm{N}}$ の 曲線の方程式を代入することにより V が算出できる.ここで, Fig. 7 に示すように, $H$ は白金るつぼの深さ $(\mathrm{m}), D$ は白金る つぼの内径 $(\mathrm{m}), H_{1}$ はるつぼ上端より上部の盛り上がった液体 の高さ $(\mathrm{m}), \mathrm{P}_{\mathrm{i}}(\mathrm{i}=1,2, \cdots, \mathrm{N})$ は測定点, $\mathrm{N}$ は測定点の数, $A_{\mathrm{i}}$, $B_{\mathrm{i}}, C_{\mathrm{i}}$ はるつぼ上端から上に盛り上がった液体部分に和いて, それぞれ $\mathrm{i}$ 番目と $\mathrm{i}-1$ 番目の水平断面の間の液面の近似式の 定数である.

\section{2. 誤差の検討}

\section{(1) 実測点数}

Fig. 7 に示すように，るつぼ上端より上部の液面形状を，軸 比 $a / b$ が $H_{1} /(D / 2)$ の場合に拈ける $z=0$ 平面より上部の半棈 円球とし，その場合の全液体の体積を $V_{0}$ とする. 半棈円球を $N$ 個の放物面円錐台で近似した場合に, 式(8)により算出さ れる全液体の体積を $V$ とする．その結果， $V_{0}$ と $V$ との差は $\mathrm{N}$ により変化するが， $V_{0}$ に対する $V$ の相対誤差は軸比に依存 せず，測定数 $N$ のみに依存する。この相対誤差と $N$ との関係 をFig. 8 に示す. Fig. 8 に扣いて, $N$ が10以上の場合， $V$ と $V_{0}$ とはほとんど一致し，その相対誤差は $0.05 \%$ 以下になる. $N$ が30以上となると, Fig. 8 に示すように, 式(8)による体 積計算誤差は $0.003 \%$ 以下に抑觉ることができる. 本研究では, メニスカスの液面線上の測定点を30〜70個取っているので, 密度の算出に及ぼす体積の計算誤差の寄与は無視できる.

\section{(2) 形状測定}

デジタイザーによる形状の測定誤差 $\Delta$ は $\pm 1.0 \times 10^{-5} \mathrm{~m}$ 以 下である. 上述の(1)の場合と同様, るつぼ上端より上部の液体 形状を半楕円球とし, その場合の全液体の体積を $V_{0}$ とし, 形 状測定の誤差により生じる体積の最大誤差を $\Delta V_{\max }$ とする. 式 ( 8)より, 形状測定に起因する密度の測定誤差は 


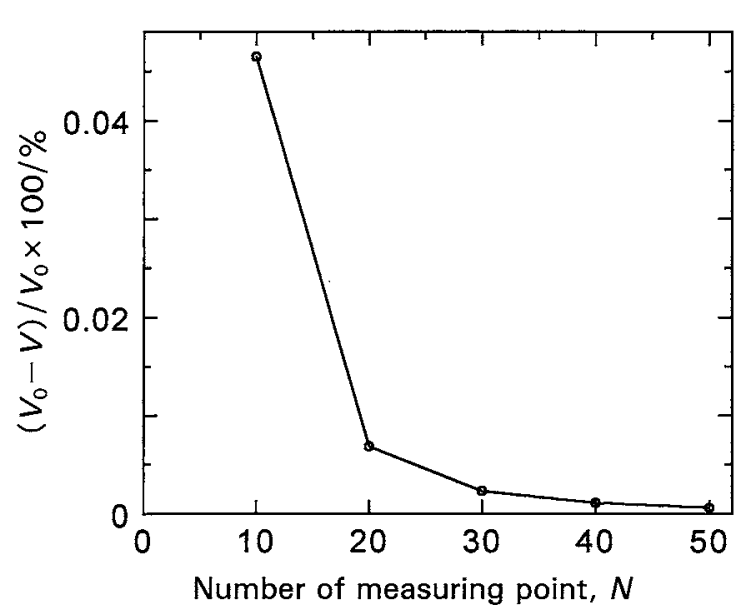

Fig. 8 Calculation error of liquid volume.

$$
\begin{aligned}
\mid \rho- & \rho_{0} \mid / \rho_{0} \times 100 \%=\Delta V_{\max } / V_{0} \times 100 \% \\
= & {\left[\pi(D+\Delta)^{2}(H+\Delta) / 4-V_{0}+\pi \int_{\mathrm{H}_{1}}^{H_{1}+\Delta}\right.} \\
& \left.\times\left(A_{\mathrm{i}} z^{2}+B_{\mathrm{i}} z+C_{\mathrm{i}}\right)^{2} \mathrm{~d} z\right] / V_{0} \times 100 \%<0.2 \%
\end{aligned}
$$

である・ $\rho_{0}$ は真の密度.

\section{(3) 水の密度の測定}

実験に際して生じる誤差を調べるために，室温でイオン交換 蒸留水の密度を測定した。実験装置をFig.9亿示す，電子天 秤 (精度が $0.001 \mathrm{~g}$ ) に水平に設置した白金るつぼに，洗浄㼛か ら蒸留水を Fig. 9 亿示すよらに水の表面がるつ济上端より上 て盛り上がるまで入れる，液面が静止後，A， B, C, D 四方向か

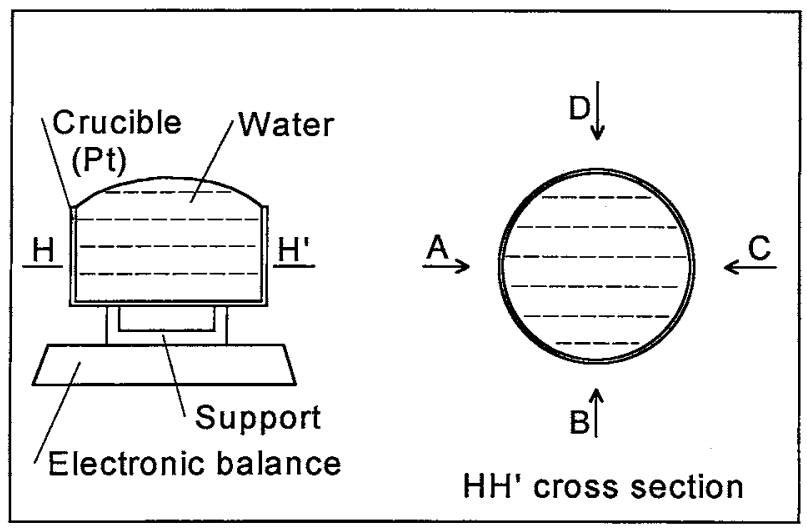

Fig. 9 Scheme of experimental apparatus for measuring the density of water.

Table 2 Density of water, $\rho / \mathrm{kg} \cdot \mathrm{m}^{-3}$.

\begin{tabular}{l|c|c}
\hline \hline Temperature, $T / \mathrm{K}$ & 291.5 & $297 \pm 1$ \\
\hline Present work & - & $994 \pm 9$ \\
\hline Archimedean method $^{(10)}$ & 1032 & - \\
\hline Standard value $^{(13)}$ & 998.5 & 997.3 \\
\hline
\end{tabular}

らるつぼと水の表面の形状を写真撮影する．撮影したるつぼと 水表面の像の形状から式 (8)を用いて水の体積を算出する. その体積と電子天秤で測った亦の質量より, 蒸留水の密度を求 める. Table 2 亿本測定法で算出した密度, 他の研究者の測定 值 ${ }^{(10)}$ ，および化学便覧䐆用されている值 ${ }^{(13)}$ を示す. Table 2 上り, 本測定法で水の質量を種々変化させて測定した水の密 度 $(297 \pm 1 \mathrm{~K})$ は 985.6 1001.9 $\mathrm{kg} \cdot \mathrm{m}^{-3}$ の間にあり, 平均値は $994 \pm 9 \mathrm{~kg} \cdot \mathrm{m}^{-3}$ となった。この值を化学便覧の值 $997.3 \mathrm{~kg}$. $\mathrm{m}^{-3}$ と比較した場合, その相対䛊差は $1.2 \%$ 以内である.

\section{N. $\mathrm{B}_{2} \mathrm{O}_{3}$ の表面張力と密度の測定}

本研究で開発した液体の表面張力と密度の測定法を溶融スラ グの表面張力と密度の測定に適用寸るために，Fig. 10 K示す 測定装置を製作した. そして, 高温での物理化学的性質が安定 で, 密度と表面張力がすでによく測定されている $\mathrm{B}_{2} \mathrm{O}_{3}$ を用い て，本測定法と装置の妥当性を検討した。

\section{1. 実験方法}

測定炉は Fig. 10 亿示すよ5に，縦型電気抵抗炉であり，4 本の発熱体と炉内はそれぞれアルミナ管で隔てられ，外気と接 する箇所はすべて゚リングンールを施し，炬内の気密性を保 持した. 白金円筒を, 上下動が可能なアルミナ管に固定された アダプターに白金線で取り付ける，予備溶解した純度が $99.8 \%$ 以上の $\mathrm{B}_{2} \mathrm{O}_{3}$ 所定量白金るつぼ(水の表面張力と密度測定用 のるのと同一寸法)に入れ，炉内に水平にせットする. 精製 $\mathrm{Ar}$ 雾囲気中 $\left(P_{\mathrm{O}_{2}}=10^{-8} \sim 10^{-9} \mathrm{MPa}\right)$ で昇温し，るつぼ内の $\mathrm{B}_{2} \mathrm{O}_{3}$ が溶解した後, 測定温度に $10 \mathrm{~min}$ 間保持してから, 溶融 $\mathrm{B}_{2} \mathrm{O}_{3}$ とるつぼの形状を A, B , C おょび D 四方问から写真撮影する.

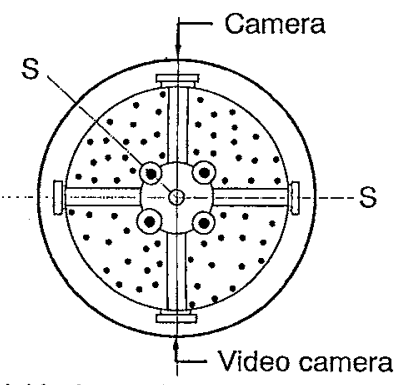

(a) Horizontal view of section at $\mathrm{HH}$

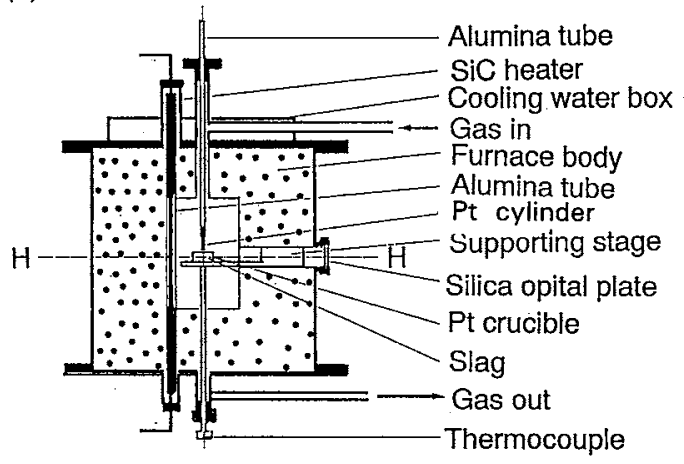

(b) Vertical view of section at SS

Fig. 10 Scheme of the experimental apparatus. 


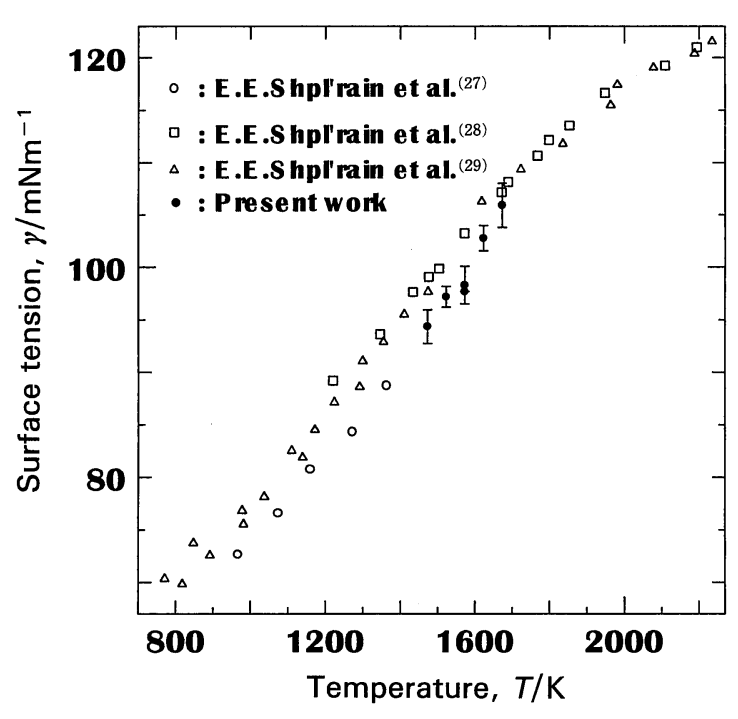

Fig. 11 Surface tension of molten $\mathrm{B}_{2} \mathrm{O}_{3}$ in argon atmosphere.

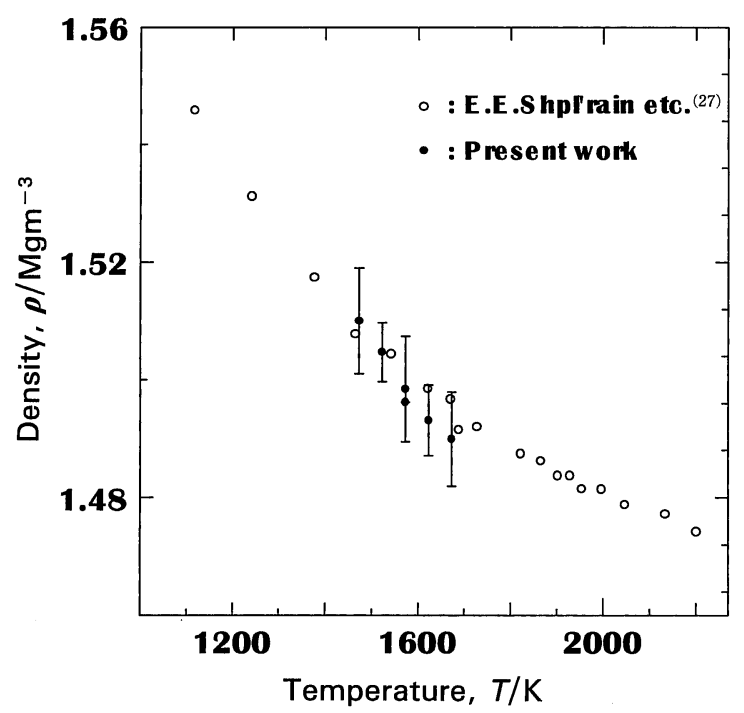

Fig. 12 Density of molten $\mathrm{B}_{2} \mathrm{O}_{3}$ in argon atmosphere.

次に，白金円筒の先端を垂直にるつぼの真中に浸漬させる．溶 融 $\mathrm{B}_{2} \mathrm{O}_{3}$ が白金円筒の表面に沿って這い上がり，メニスカスを 形成した後, $5 \mathrm{~min}$ 間保持してから，メニスカスとるつぼの形 状を写真撮影する，撮影された写真から，白金円筒を浸漬する 前の溶融 $\mathrm{B}_{2} \mathrm{O}_{3}$ 液面とるつぼの形状, および浸漬後の白金円筒 の周囲に形成されたメニスカスの形状をデジタイザーを用いて 測定する.

\section{2. 測定結果}

1473〜 $1673 \mathrm{~K}$ の各測定温度で得られた $\mathrm{B}_{2} \mathrm{O}_{3}$ の表面張力と 密度の測定結果をとれぞれFig. 11 と Fig. 12 亿示す. Fig. 11,12 亿打いて, $\mathrm{B}_{2} \mathrm{O}_{3}$ の表面張力と密度の測定值は従来の測 定値 ${ }^{(14)-(16)}$ とょく一致している. 本測定法で得られる測定の バラッキは, 相対誤差にして, 密度の場合で士1.3\%, 表面張
力の場合では $\pm 1.9 \%$ 以内である.

\section{$\mathrm{V}$. $\mathrm{Fe}_{t} \mathrm{O}-\mathrm{SiO}_{2}-\mathrm{Al}_{2} \mathrm{O}_{3}$ 系スラグの表面張力と密度の測 定}

\section{1. スラグ}

$\mathrm{SiO}_{2}$ 成分としては純度 $99.99 \%$ の石英管を粉砕し，王水拉よ

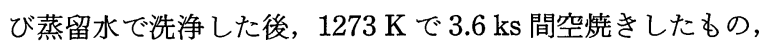
$\mathrm{Fe}_{t} \mathrm{O}$ 成分には市販の $\mathrm{FeO}$ 試薬, $\mathrm{Al}_{2} \mathrm{O}_{3}$ 成分には市販の特級 $\mathrm{Al}_{2} \mathrm{O}_{3}$ 試薬を用いた. それぞれ所定の割合に秤量したものを十 分に混和してから，極軟鋼質るつぼに入れ，綎型の電気抵抗炉 を用い, $1673 \mathrm{~K}$, 精製した $\mathrm{Ar}$ 䨌囲気で溶融し, $7.2 \mathrm{ks}$ 保持し てから室温まで降温する. 凝固後のスラグを粒状に粉䂶し, こ の粒状スラグを測定用スラグとして使用した.

\section{2. 測定操作}

測定操作は $\mathrm{B}_{2} \mathrm{O}_{3}$ の測定の場合と基本的には同じである．た だし，緒言で述べたように，スラグの場合は $P_{\mathrm{O}_{2}}$ を局部溶損観 察時と同じ值に制御する目的で, 白金るつぼの周りの等温部に 電解鉄を置き，次の反応により $P_{\mathrm{O}_{2}}$ を制御する方法を用いた.

$$
\mathrm{Fe}(\mathrm{s})+1 / 2 \mathrm{O}_{2}(\mathrm{~g})=\mathrm{FeO}(\mathrm{s})
$$

\section{3. $\mathrm{Fe}_{t} \mathrm{O}-\mathrm{SiO}_{2}$ 系スラグの表面張力と密度}

$1673 \mathrm{~K}$ 亿括ける $\mathrm{Fe}_{t} \mathrm{O}-\mathrm{SiO}_{2}$ スラグの表面張力, 密度と組成 との関係をそれぞれ Fig. 13 と Fig. 14 亿示す. 表面張力, 密 度とも $\mathrm{SiO}_{2}$ 成分の濃度の増大とともに減少する. 本測定法で 得られる測定值のバラッキは, 相対誤差にして, 密度の場合で $\pm 2.2 \%$, 表面張力の場合では $\pm 2.9 \%$ 以内である.

本測定で得られた表面張力の值は, 従来の測定値 ${ }^{(8)(17)}$ とほ ぼ一致するが, $\mathrm{SiO}_{2}$ 濃度に対する表面張力の減少割合は本測 定結果の方がすこし大きい. 本測定による密度は, 従来の測定 結果(18)-(26)の範囲内にあるが，その中では低めの值に属する. 表面張力の従来の測定値は, 緒言に述べたように, 例えば, 最

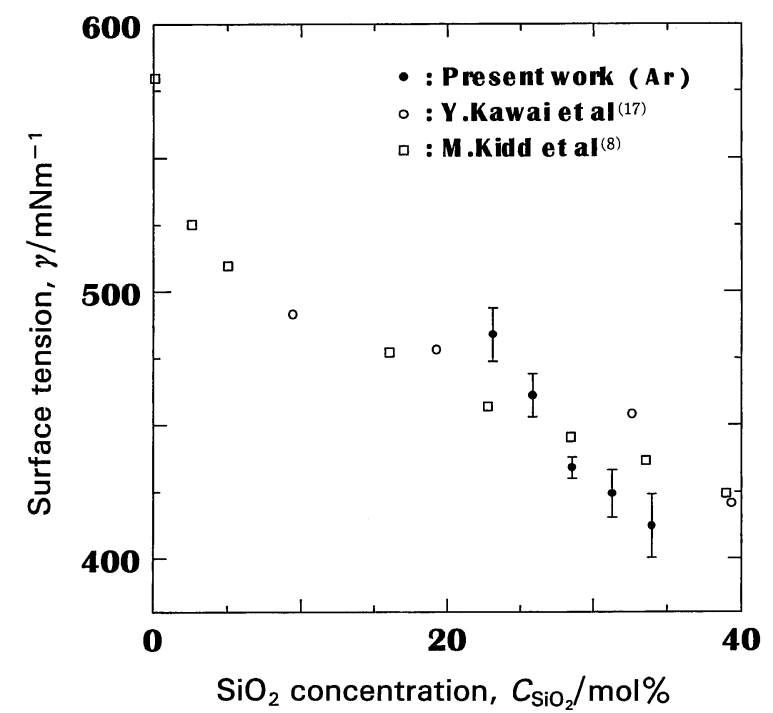

Fig. 13 Surface tension of $\mathrm{Fe}_{t} \mathrm{O}-\mathrm{SiO}_{2}$ slag at $1673 \mathrm{~K}$. 


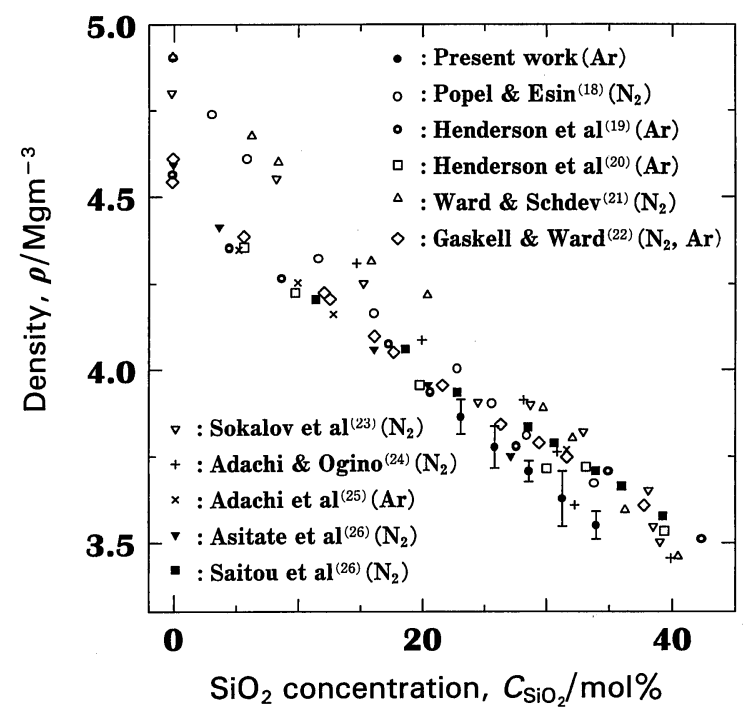

Fig. 14 Density of $\mathrm{Fe}_{t} \mathrm{O}-\mathrm{SiO}_{2}$ slag at $1673 \mathrm{~K}$.

大泡圧法と浸漬円筒法の場合では, 測定時の動的効果(表面の 拡張) 或いは測定用雾团気中の $P_{\mathrm{O}_{2}}$ の制御の難しさ, Paddy Cone 法の場合では, 他の測定法で得た密度を使用しなければ ならないなどの問題点を持っている. 本測定法では, 十分に静 的な状態で表面張力が測定され，しかも測定対象のスラグの表 面は炉内雾囲気と同じである. 表面張力の $\mathrm{Fe}_{t} \mathrm{O}$ 濃度依存性が Fig. 13 に示すように他の測定法と異なることについては, 各 測定法が持つ上記のよらなスラグ表面についての測定状態の相 違が関与している可能性が考えられる. また, 密度の $\mathrm{Fe}_{t} \mathrm{O}$ 濃 度依存性が従来の測定結果とほぼ一致する(Fig. 14)こと（すな わち密度のようなスラグ相本体の性質は, 相本体の組成が同じ であれば，同じ傾向が得られること）も，上記の可能性を支持 するものと考觉らる.

密度の測定值が低めの傾向を示すのは, 本測定では白金るつ ぼを使用しており，スラグは固体鉄と直接に接触しないので,

$$
\mathrm{Fe}(\mathrm{s})+2 \mathrm{Fe}^{3+}=3 \mathrm{Fe}^{2+}
$$

等の反応による $\mathrm{Fe}^{2+}$ の生成が困難な状態にあることが原因の 一つとして考えられる. 何故なら, 森, 鈴木 ${ }^{(9)}$ によば, $\mathrm{Fe}^{2+}$ は溶融 $\mathrm{FeO}$ の密度を増加させるからである.

表面張力測定において，川合ら ${ }^{(17)}$, Kidd と Gaskell(8) 教鉄る つぼを用いているので, Fig. 13 亿示す表面張力の $\mathrm{Fe}_{t} \mathrm{O}$ 濃度 依存性の相違には, 上記のスラグの表面についての測定状態の 相違だけでなく, $\mathrm{Fe}^{2+}$ 濃度の相違が関与している可能性も考 えられる. それ故, この相違の具体的理由については, な抾不 明であり, 今後の研究課題として残される.

\section{4. $\mathrm{Fe}_{t} \mathrm{O}-\mathrm{SiO}_{2}-\mathrm{Al}_{2} \mathrm{O}_{3}$ 系スラグの密度と表面張力}

$1673 \mathrm{~K}$ に括ける $\mathrm{Al}_{2} \mathrm{O}_{3}$ が 9 mass\%の三元系スラグの表面張 力, 密度と組成との関係をそれぞれ Fig. 15 と Fig. 16 に示 す. 図に示すように, $\mathrm{Fe}_{t} \mathrm{O}-\mathrm{SiO}_{2}$ スラグ系と同様, 表面張力, 密度とも $\mathrm{SiO}_{2}$ 成分の濃度の増加とともに減少する. しかし, $\mathrm{SiO}_{2}$ が $30 \mathrm{~mol} \%$ 以下では, 表面張力の $\mathrm{SiO}_{2}$ 濃度に対する減 少割合は, $\mathrm{Fe}_{t} \mathrm{O}-\mathrm{SiO}_{2} 2$ 成分系より大きくなる. 密度は,

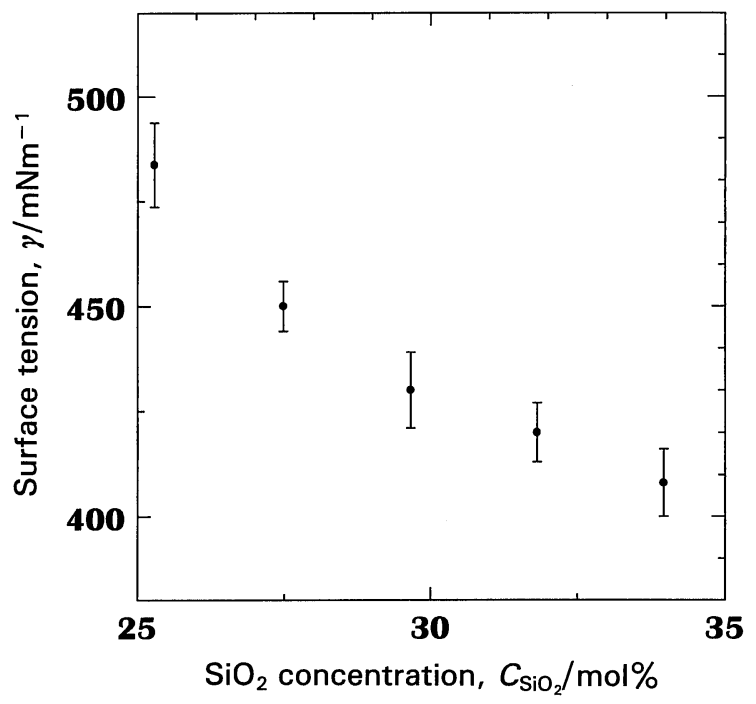

Fig. 15 Surface tension of $\mathrm{Fe}_{t} \mathrm{O}-\mathrm{SiO}_{2}-9$ mass $\% \mathrm{Al}_{2} \mathrm{O}_{3}$ slag at $1673 \mathrm{~K}$.

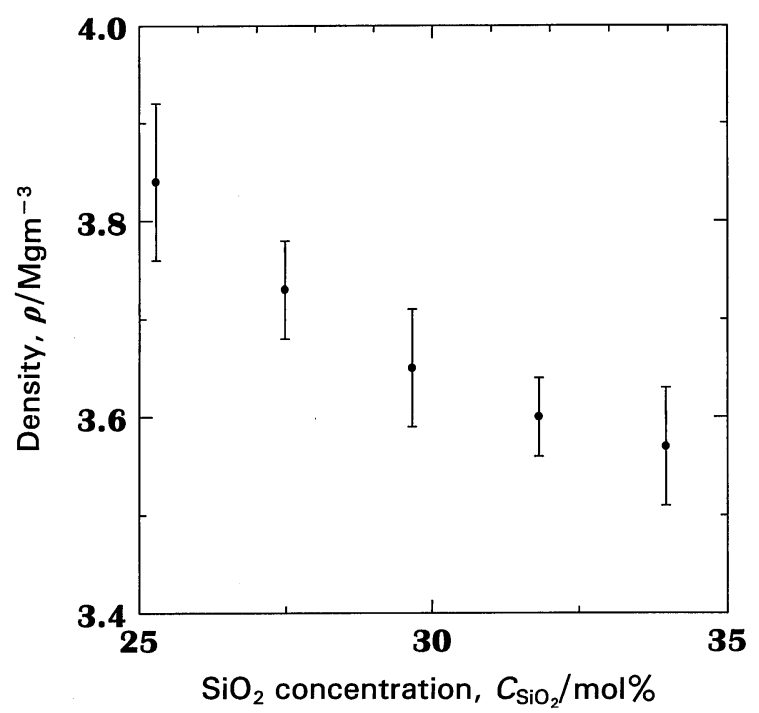

Fig. 16 Density of $\mathrm{Fe}_{t} \mathrm{O}-\mathrm{SiO}_{2}-9$ mass $\% \mathrm{Al}_{2} \mathrm{O}_{3}$ slag at $1673 \mathrm{~K}$.

$\mathrm{Al}_{2} \mathrm{O}_{3}$ をこの程度添加してもほとんど変化しない.

また，本測定法で得られる測定のバラッキは，相対誤差にし て, 密度の場合で士2.1\%, 表面張力の場合では $\pm 2.4 \%$ 以内で ある。

\section{V. 結 言}

被測定液体に垂直に浸漬した円筒に沿って生じる液体のメ二 スカスの形状を測定, 解析することによって, 表面張力を精度 良く測定できる方法を開発した．本法は，静滴法では測定困難 な静滴と基盤との接触角が $90^{\circ}$ 以下の測定系の表面張力を, 静 的条件のむとで雾囲気の酸素分圧を十分に制御した状態で測定 できる. 
さらに，表面張力の測定と同時に，円筒るつぼに入れた液体 の体積から密度を測定する方法を開発した。

本法の測定精度を, 室温でのイオン交換蒸留水を用いて調べ た結果, 表面張力, 密度とも化学便覧の推奖の值 ${ }^{(12)}$, 標準 值 ${ }^{(13)}$ との差はいずれも相対䛊差にして $1.2 \%$ 以内にあり，最大 泡厈法より高いものであることが明らかになった。

本法を用いて溶融酸化物の表面張力と密度を同時に測定する ための装置を製作し，まず，高温で物理化学的性質が比較的安 定な $\mathrm{B}_{2} \mathrm{O}_{3}$ の密度と表面張力を測定した．その値を既報の最大 泡厈法による測定值と比較した結果，この测定装置が高い測定 精度を持つものであることが明らかになった，本測定装置で得 られる測定値のバラッキは，相対誤差にして，密度では $\pm 1.3 \%$, 表面張力では士 $1.9 \%$ 以内である.

本測定装置を用いて， $\mathrm{Fe}_{t} \mathrm{O}-\mathrm{SiO}_{2}$ スラグ系の表面張力と密度 を良好な測定精度で測定することができた，得られた結果を従 来の測定結果と比較検討し，妥当な解釈を与兄ることができ た. $\mathrm{Fe}_{l} \mathrm{O}-\mathrm{SiO}_{2}$ スラグに $\mathrm{Al}_{2} \mathrm{O}_{3}$ を 9 mass\%添加しても, 表面 張力, 密度の絶対值扣よび組成依存性に大きな変化はないが, 表面張力の $\mathrm{SiO}_{2}$ 濃度に対する減少割合は $30 \mathrm{~mol} \%$ 以下で, $\mathrm{Fe}_{t} \mathrm{O}-\mathrm{SiO}_{2} 2$ 成分系より大きくなる。

\section{文献}

（1）余 仲達，向井楠宏：日本金属学会誌，56(1992), 1137.

(2) C. F. Cooper and J. A. Kitchener: JISI., 193(1959), 48.

(3) T. B. King: J. Soc. Glass Techn., 35(1951), 241.

(4) 向井楠宏, 石川友美 : 日本金属学会誌, 45(1981)，147.

(5) S. I. Popel and D. A. Esin: Zn. Neorg. Khim., 2(1957),
632.

(6) J. F. Padday: J. C. S. Faraday, Trans. I, 75(1979), 2827

(7) I. Jimbo and A. W. Cramb: ISIJ International, 32(1992), 26.

(8) M. Kidd and D. R. Gaskell: Metallurgical Trans. B, 17B(1986), 771.

（9）森一美, 鈴木 鼎：鉄と鋼，54(1968), 1123.

（10）荻野和已，原 茂太 : 鉄と鋼, 63(1977)，2141.

（11）小野清雄, 郡司好喜, 荒木 透：日本金属学会誌, $33(1969), 299$.

（12）日本化学会：化学便覧基礎編 II，(1975), 610 .

（13）日本化学会：化学便覽基礎編 II，(1975), 667 .

(14) E. E. Shpl'rain, K. A. Yakimovich and A. F. Tsitsarkin: Teplofiz. Vys. Temp., 9(1971), 67.

(15) E. E. Shpl'rain, K. A. Yakimovich and A. F. Tsitsarkin: High Temp. High Press., 4(1972), 67.

(16) E. E. Shpl'rain, K. A. Yakimovich and A. F. Tsitsarkin: Teplofiz. Vys. Temp., 12(1974), 77.

（17）川合保治，森 克巳，白石博章，山田 昇：鉄と鋼, 62(1976), 53.

(18) S. I. Popel and O. A. Esin: Zhur Prike Khim., 29 (1956), 651.

(19) J. Henderson, R. G. Hudson, R. G. Ward and G. Derge: Trans. Met. Soc. AIME, 221 (1961), 80.

(20) J. Henderson: Trans. Met. Soc. AIME, 230(1964), 501.

(21) R. G. Ward and P. L. Schdev: Trans. Met. Soc. AIME, $233(1965), 1496$.

(22) D. R. Gaskell and R. G. Ward: Trans. Met. Soc. AIME, 239 (1967), 249.

(23) V. I. Sokolov, S. I. Popel and O. A. Esin: Izv. VUZ Chern. Met., 2(1970), 10.

(24) A. Adachi and K. Ogino: Technol. Rep. Osaka Univ., 12 (1962), 147.

(25) A. Adachi, K. Ogino and S. Kawasaki: Technol. Rep. Osaka Univ., 12(1963), 411.

（26）溶鋼-溶㳯の物性值便覧，特別報告書 No. 12 , 日本鉄鋼 協会 (出版)，(1972), 24. 